\title{
Islands in the energy stream: regional cooperation in the Indian Ocean tourism sector
}

\section{Roy SMITH, Rachel WELTON \\ Nottingham Business School, Nottingham Trent University, UK}

\begin{abstract}
:
Aim: This article considers the need to move away from a dependency on fossil fuels towards more sustainable renewable sources of energy production. The focus is on the tourism sector in two Indian Ocean destinations, Mauritius and the Seychelles. The broader aim, however, is to highlight the interconnectedness between public and private stakeholders and how lessons learned from these case studies could have broader applicability elsewhere.
\end{abstract}

Design/research methods: A case study approach has been taken drawing on data supplied by both the private tourism sector in the destinations under consideration and relevant government and regional reports.

Conclusions/findings: Progress has been made in the shift towards decarbonisation policies and practices in these destinations. This has been achieved via a cooperative approach between public and private stakeholders, extending the development of renewable energy infrastructure and supply to include sustainable education policies supported by both governments' education departments and vocational programmes implemented by the larger hotels in these destinations.

Originality/value of the article: Although there have been other studies conducted on the promotion of renewable energy in small island states, there is a paucity of such research looking specifically at the tourism sector and the role of public/private partnerships in developing broader education for sustainable development programmes.

Implications: The case studies focus on highlighting how governments and tourism businesses can work towards shared goals, in this case decarbonisation and education for sustainability. The implication is that such a model could be applied elsewhere with equally positive results.

Key words: Sustainable development, tourism, energy security

Correspondence address: Roy SMITH, Rachel WELTON, Nottingham Business School, Nottingham Trent University, UK E-mail: roy.smith@ntu.ac.uk (Roy Smith), rachel.welton@ntu.ac.uk (Rachel Welton).

Received: 28.05.2019, Revised: 13.12.2019, Revised: 14.02.2020, Accepted: 15.03.2020

doi: http://dx.doi.org/10.29015/cerem.831 


\section{Introduction}

The intersecting nexus between current mainstream, fossil fuel-based energy production, subsequent climate change impacts and the need to manage sustainable patterns of production and consumption are the most pressing issues in contemporary domestic and international politics (McKendry 2002). The Intergovernmental Panel on Climate Change (IPCC) has repeatedly warned of the need for a shift towards more renewable energy sources to avoid excessive global warming and the catastrophic impacts this is likely to have due to increasing and more extreme weather events (IPCC 2011). Groups such as Extinction Rebellion are raising the profile of this issue through direct action events and there is a clear sense that this message is resonating with a growing number of city authorities and political parties calling for national climate emergencies to be declared (Shah 2019). A precise definition of what such an emergency entails and exactly how to respond remains rather vague. That said, there can no longer be any doubt that significant changes are required to both mitigate against further climate-related risks and to adapt to those environmental challenges that are already occurring (Oreskes 2004; IPCC 2007).

In the so-called age of the Anthropocene, where future changes on a global scale are largely being driven by human activity, there is a requirement to recognize the scale and complex nature of multiple climate emergencies (Hughes et al. 2017). It is also important to be aware that to manage a coherent and sustainable response to these emergencies it is necessary to involve multiple stakeholders from cooperation between regional governments, through to including private sector initiatives and civil society groups down to the level of individual households or businesses (Pinkse, Kolk 2012). Everyone requires energy in some form or another. Not only for immediate household power consumption but also for the production and maintenance of everyday goods and services that are central aspects of modern life. How such energy is produced and consumed varies considerably, both in nature and scale (Asif, Muneer 2007). To make sense of this on a global scale is almost impossible with so many actors and other variables in play. For this task to be more manageable it is useful to focus on relatively small, self-contained territories such as 
small island states. While they are connected to global processes of climate change, in many cases they are among the communities most vulnerable to these risks. They can provide insightful coherent case studies for examining the roles and agendas of the varying stakeholders that need to cooperate in order to address and sustainably manage the challenges and opportunities involved in developing and implementing integrated renewable energy policies and practices.

This article considers energy security issues in the Southwest Indian Ocean, focussing on Mauritius and the Seychelles. Both small island developing states (SIDS) have tourism sectors that are key aspects of their national economies, which currently rely heavily on imported fossil fuels. They are also members of the Indian Ocean Commission (IOC) and the Indian Ocean Rim Association (IORA). These bodies provide institutional frameworks for their members to cooperate in addressing shared challenges. In May 2018 the IOC convened the first Regional Renewable Energy Forum for the Indian Ocean, held in Mauritius (IRENA 2019) In some respects, it is surprising that this event had not happened sooner, given that energy security in SIDS has long been recognised as an issue (Wolf et al. 2016). Both Caribbean and Pacific SIDS appear to be more advanced in discussing and tackling these issues in their respective regional institutions. Here we briefly outline the global drive towards tackling energy security issues, including regional initiatives, and then focus on Mauritius and the Seychelles in terms of relevant stakeholders and the drivers and possible blockers to achieving sustainable energy security.

The United Nations Sustainable Development Goals include SDG 7, which aims to 'ensure access to affordable, reliable, sustainable and modern energy for all' (UNDP 2019). Despite some sporadic, residual climate change denial, most the world's climate scientists and policymakers now recognise that environmental damage is caused by anthropogenic greenhouse gas emissions (Zeebe 2013). The State of the Climate report 2018, produced by the World Meteorological Organization revealed that more than 90 per cent of the energy trapped by greenhouse gases goes into the oceans and whilst not wholly attributable to the burning of fossil fuels, this is a leading cause of air pollution and the acidification of the oceans as the $\mathrm{CO}_{2}$ is absorbed. The Conference of the Parties to the International 
Convention on Climate Change meets on a regular basis, COP21 was held in Paris in December 2015. This led to a historic agreement where 195 countries adopted the first ever legally binding global climate deal (Robbins 2016). Not all these countries subsequently ratified this agreement, notably the Trump administration of the United States. However, this agreement did demonstrate a higher level of political commitment to seriously addressing the issue of climate change than had previously been the case. SIDS have been at the forefront of calling for meaningful action to address these issues as some of the communities most at risk from climate change and sea-level rise.

The UN Conference on Sustainable Development in SIDS was held in the Caribbean in 1994. This led to the Barbados Action Plan, which is a fourteen-point programme that identified both energy resources and tourism resources as priority areas (United Nations 2008). The Caribbean Community (CARICOM 2019a) Secretariat launched an Energy Programme in 2008 within its Directorate of Trade and Economic Integration (CARICOM 2019b). Other sectors of regional government concern have also been addressed in a similar manner, but this indicates both an awareness of the significance of energy security issues and also recognition of the need to adopt a collaborative regional approach to tackling these issues. In the Pacific region there are two key regional organisations, the Pacific Islands Forum (PIF) and the Secretariat of the Pacific Community (SPC). In 2014 a meeting of Pacific Ministers of Energy and Transport endorsed the establishment of the Pacific Centre for Renewable Energy and Energy Efficiency based in Tonga. PCREEE is a multi-stakeholder partnership between Pacific Island governments, the UN Industrial Development Organization (UNIDO), the SIDS Sustainable Energy and Climate Resilience Initiative and the Austrian Development Agency (ADA) (PCREEE 2019). This is a good example of how SIDS work, not only with each other, but also with major inter-governmental agencies and donor partners, who are sometimes based well outside of the region in question.

International collaboration on renewable energy has a long history with a milestone event taking place in 1981 with the proposal for the creation of an International Renewable Energy Agency (IRENA). Despite general support for this proposal from the majority of the world's governments the founding conference of 
IRENA did not take place until 2009 in Bonn. This provides some insight into how complex and longwinded intergovernmental negotiations can be, even when there is broad agreement on the need for action. More positively, once established, IRENA has been very active in relation to the promoting of renewable energy production, including in SIDS. Launched in 2014 IRENA's SIDS Lighthouses Initiative has a target of 2020 to: 1) Ensure all participating islands develop renewable energy roadmaps, 2) Mobilise \$US 500 million and 3) Deploy 120 megawatts of renewable energy capacity. Both Mauritius and the Seychelles are part of this initiative. According to a 2015 Quickscan analysis conducted by IRENA Mauritius is more advanced than the Seychelles in its transition from reliance on fossil fuels to renewable energy sources (IRENA 2019).

IRENA's analysis is based on seven categories of indicators: 1) Institutional Framework; 2) Knowledge Base; 3) Planning; 4) Financing; 5) Deployment; 6) Capacity Building and 7) Cooperation. Given that Mauritius and the Seychelles are roughly comparable in many ways regarding energy security and have both engaged in regional energy security initiatives it is surprising that they are making differing rates of progress. There are some notable differences with Mauritius importing 52\% of their commercial energy in the form of petroleum, compared to a significantly higher figure of $95 \%$ for the Seychelles (Hadush, Bhagwat 2019). Arguably this should provide an even greater incentive to the Seychelles to address this issue. Having a national regulatory body for the energy sector is a fundamental aspect of monitoring and advancing the energy security agenda. Given the relative advantage Mauritius appears to have over the Seychelles, according to the IRENA analysis, it is also surprising to discover that the Seychelles established its Seychelles Energy Commission in 2009, whereas the equivalent Mauritian Utility Regulatory Authority was not established until 2016 (IRENA 2019).

The issue of regulation is important as it is central to developing a coherent national action plan and to ensure that governments have the necessary oversight and power to intervene and guide the energy sector towards the desired transition from fossil fuel dependency to more sustainable sources of renewable energy. In terms of a theoretical approach, such regulatory bodies can be viewed from a neoFunctionalist perspective adopting the adage of 'form follows function'. This is an 
approach developed by Ernst Haas and David Mitrany, initially in relation to the formation of what was to eventually become the European Union (Haas 1968). However, it can be applied equally well to CARICOM, PIF, SPC, IORA or the IOC. Notably one of the most significant outcomes of the IOC's Regional Renewable Energy Forum was the creation of the Association of Energy Regulators Indian Ocean. This body is intended to both ensure that all the IOC member states have regulatory bodies overseeing the energy sector and that they are collaborating in line with a common agenda. Importantly this body will also need to collaborate with other relevant state agencies dealing with economic development and environmental protection. Such collaborative efforts will also overlap with intergovernmental bodies, relevant non-governmental organisations and the private sector. Regarding the latter, the tourism sector is a major consumer of energy and, therefore, crucial to engage with in order to promote and facilitate the transition to a low-carbon economy.

This paper aims to examine the transition of two island states in the Indian Ocean to adopt more renewable energy sources and reduce their dependency on fossil fuels, within the context of the climate crisis. Mauritius and the Seychelles are both dependent upon fossil fuel reliant tourism for economic growth. On the one hand the public sector has natural resources that can provide energy and yet the infrastructure required to produce and supply renewables is often financially prohibitive. For the private sector energy issues focus tends to be energy efficiency, sustainability and cost reduction. These issues are explored initially by reviewing the energy requirements of the tourism sector and the greenhouse gases generated through transport and accommodation in tourism. This is followed by a review of the energy policies and ensuing tourism policies and how these are addressed through tourism education in Mauritius and the Seychelles. Finally, the interconnectedness between public and private stakeholders is examined with key points highlighted to provide broader applicability for islands. 
ISLANDS IN THE ENERGY STREAM: REGIONAL COOPERATION IN THE INDIAN ...

\section{Tourism and energy}

In most island states tourism is the major economic sector and provides potential to generate foreign exchange earnings, increase foreign investments and through this reap the benefits of increased tax revenues, create new jobs and promote the nation in the global arena. As outlined by United Nations World Tourism Organization (UNWTO 2012), tourism represents a unique opportunity because it is less subject to, and can actually benefit from factors that are barriers to other forms of economic growth: small and dispersed populations, small land areas, remoteness from markets, and limited natural resources.

Within the Indian Ocean region there are some success stories as tourism has directly benefited the economies of both the Seychelles and Mauritius over the last decade and some key lessons can be learnt from their experiences. Mauritius has increased tourism arrivals at a phenomenal rate. In 1995 there were 315,000 international tourism arrivals and tourism receipts were US\$211 million. In 2014 tourism arrivals exceeded 1.2 million (380\% increase) and tourism receipts had grown to US\$2,645 (Ministry of Tourism 2014). In 1995 the Seychelles had 120,716 tourist arrivals and this had increased to 231,857 in 2014 (92\% increase) (NBS 2018). Both Mauritius and Seychelles experienced economic challenges and have had to adjust the generating region of the tourist arrivals (China for Mauritius and India, South Africa \& Russia for the Seychelles) to ensure a constant supply of international tourists with foreign exchange is maintained. Mauritius has experienced less instability in the economy and has also used a trade policy to protect the domestic industries of sugar, export processing zones (EPZs) and tourism was used to underpin this economic growth.

International tourist arrivals have increased from 25 million globally in 1950 to 278 million and exceeded 1 billion in 2015. Likewise, international tourism receipts earned by destinations worldwide have surged from US\$ 2 billion in 1950 to US\$ 1,220 billion in 2016 (UNWTO 2017). The Indian Ocean islands of the Seychelles and Mauritius have both seen substantial growth in this sector of their economies. UNWTO (2017) states, international tourist arrivals in Africa increased by an estimated $8 \%$ in 2016 according to the comparatively limited data available to date, 
representing a strong rebound after a weaker performance in 2014 and 2015 in the wake of various health, geopolitical and economic challenges. The region welcomed 58 million international tourists in 2016 (5\% of the world total), 4 million more than in 2015, earning US\$ 35 billion in international tourism receipts (3\% share), an increase of $8 \%$ in real terms. Sub-Saharan Africa (+10\%) had the highest increase across all world sub regions. South Africa, the sub region's top destination, enjoyed $13 \%$ growth in international arrivals, partly thanks to simpler visa procedures. Kenya $(+17 \%)$ and Tanzania $(+16 \%)$ also boasted double digit growth in 2016, rebounding from weaker figures in 2015. Island destinations Madagascar $(+20 \%)$, Cabo Verde $(+15 \%)$, Mauritius $(+11 \%)$ and the Seychelles $(+10 \%)$ also posted double-digit growth.

\section{Greenhouse gas emissions from tourism}

The growth in tourism arrivals means that there are increases in energy requirements within the tourism industry. Tourism-related energy use and associated emissions of GHGs can be organized into three subsectors: transport to and from the destination, accommodation and activities (see UNWTO, UNEP, WMO 2008). Within this the transport sector, including air, car and rail, generates the largest proportion, with $75 \%$ of all emissions. The accommodation sector accounts for approximately $20 \%$ of emissions from tourism. This involves heating, airconditioning and the maintenance of bars, restaurants, pools and so on. Clearly, this varies according to the location size and type of the accommodation. Finally, activities such as diving, museums, theme parks, events or shopping also contribute to certain amounts of emissions (approx. 3.5\%) (UNWTO 2007). The current trends show that there is an increase in air travel over surface travel. In 2016, slightly over half of all overnight visitors travelled to their destination by air $(55 \%)$, while the remainder travelled by surface transport $(45 \%)$ - whether by road (39\%), rail (2\%) or water $(4 \%)$. The trend over time has been for air transport to grow at a somewhat faster pace than surface transport, thus the share of air transport is gradually increasing (UNWTO 2017) 
A recent UNWTO report (2018) reviewing tourism as a developmental tool established many positive prospects for destinations identifies that tourism produces profound and wide-ranging impacts across all dimensions of sustainable development. It also highlights that challenges persist such as tourism's susceptibility to market influences; over-dependence on tourism; issues of overcrowding; concerns over working conditions; emissions and pollution; potential adverse effects on biodiversity, heritage and communities; and a lack of comprehensive data on tourism's impacts on all aspects of sustainability.

Tourism is a significant contributor to greenhouse gas emissions (GHG). There are different views on the extent to which tourism contributes. The UNWTO (2008) states an estimated $5.2 \%-12.5 \%$ of $\mathrm{CO}_{2}$ emissions, the lower estimate does not take into account the radiative forcing of all greenhouse gasses (the range is attributed to the uncertainty in the role of aviation induced cirrus clouds in trapping heat) (UNWTO 2008). A more recent study, in "Nature Climate Change", estimates that global tourism, including transportation, accommodations, activities, food consumption, and all the energy and infrastructure required to accommodate visitors accounts of $8 \%$ of global emissions worldwide (Lenzen 2018). This is a considerable increase in the estimates used from the UNWTO on which the climate change reduction targets are based.

The continued growth of the tourism industry over the last six decades demonstrates that as the industry expands and diversifies to respond to shocks and takes advantage of new opportunities through the development of many new tourism destinations. The UNWTO produced a 'Business as Usual' scenario that considered increases in demand and mitigation initiatives the industry could keep within the IPCC recommendations of the 2 degrees (UNWTO 2008). However, it seems likely that the IPCC will be reducing the temperature increase target to 1.5 degrees (IPCC 2018). This is more in line with recommendations from over a hundred Small Island Developing States, Least Developed Countries and many others who have been calling for limiting global temperature rise to below $1.5^{\circ} \mathrm{C}$ above pre-industrial levels (Climate Analytics 2018). Thus if there continues to be the rate of growth that the UNWTO are forecasting and the IPCC reduce the target to 1.5 degrees the 
tourism industry would be out of kilter with the target and this could lead to a stronger public focus upon tourism strategies and policies with some uncomfortable questions for the industry to answer.

The Mauritius and Seychelles governments have both engaged with the United Nations Framework Convention on Climate Change and related negotiations to reduce greenhouse gas emissions. Notably both are signatories to the Paris Agreement, which entered into force on $4^{\text {th }}$ November 2016. The Agreement commits both states to work towards keeping the increase in global average temperature well below $2^{\circ} \mathrm{C}$ above pre-industrial levels and to limit the increase to $1.5^{\circ} \mathrm{C}$. Clearly, there is only so much individual governments can achieve, especially when they are not among the leading polluters. The international reporting of the CoP21 meeting tended to focus on aggregate global figures and targets. Whilst these are important, it is what is being legislated for and implemented at the national level that is more meaningful. Seychelles' Minister for the Environment, Didier Dogley, described the Paris meeting as a turning point in these negotiations and highlighted the need to address the extreme weather events that were negatively affecting Seychelles and other SIDS (Seychelles News Agency 2016). The Mauritian delegation to the signing of this Agreement echoed these sentiments. However, closer examination of the two states national planning towards sustainable development and converting to lower carbon economies show differing approaches. Both are working towards the same goals, but when comparing the Intended Nationally Determined Contribution (INDC) submissions to the Paris meeting there are some notable differences in terms of how each government lays out its approach, the level of coordination between Ministries and reference to partnerships with relevant stakeholders.

The INDC for Mauritius is notable in that it omits any direct reference to the tourism sector. Arguably this is implied but, given the importance of this sector to the Mauritian economy, it is surprising that it is not highlighted more explicitly. There are several references to a proposed transition to more renewable energy sources. Under a section on 'Mitigation contributions' there is reference to a proposed expansion of solar, wind and biomass energy production. Under 'Adaptation Measures' the sectors listed are 'Infrastructure; Disaster Risk Reduction 
ISLANDS IN THE ENERGY STREAM: REGIONAL COOPERATION IN THE INDIAN ...

Strategy; Coastal Zone Management; Rainwater Harvesting; Desalination; Integrated Pest and Disease Management; Efficient Irrigation Techniques Development; Climate Smart Fisheries; Improve Marine and Terrestrial Biodiversity Resilience; Health Sector and Transportation'. Again, given the scope of the measures listed here, the tourism sector is noticeably absent from this list. In terms of means of implementation the government's focal point is its Ministry of Environment, Sustainable Development and Disaster and Beach Management (MOESDDBM). This does show a degree of cross-sector thinking and administration in dealing with these interconnected issues, but is also indicative of SIDS governments more generally where the limitations of the public sector means that Ministers often have responsibility for several portfolios.

In comparison the Seychelles INDC appears more comprehensive and makes numerous references to the centrality of the tourism sector in relation to energy usage and the consequences for climate change adaptation. In terms of governance the Seychelles has a designated Department of Energy and Climate Change (DECC) within its Ministry of Environment and Energy and Climate Change. The INDC lists a number of sectors with identifiable 'vulnerabilities'. These are 'Critical Infrastructure; Tourism; Food Security; Biodiversity; Water Security; Energy Security; Health and Waste'. Under the Adaptation section of this submission it is reported that 'The key economic sector is tourism and this sector requires nimble, adaptive responses, particularly where its success is predicated on proximity to the coastal and island areas. Tourism tends naturally to adapt to market forces and the suitability of the tourism offering for the future will need not only to recognise market pressures but also those driven by climate change' (Republic of Seychelles 2015). This is a far more explicit acknowledgement of the centrality of the tourism sector, and how it is impacted by climate change, than that presented by Mauritius. The Seychelles also have a more inclusive 'vision' which is to 'minimise impacts of climate change through sustained action at all levels of society' (Republic of Seychelles 2015). There are several components to this vision with, again, an explicit reference to the importance of the tourism sector. This goes further than simply recognising that tourism is a major source of income generation for the economy. As part of this vision there is a call for 'Training in climate change for 
hoteliers and the tourism students at the Seychelles Tourism Academy'. It is not made clear exactly what this training would involve but it is significant that this is something that is being acknowledged as necessary and resources are being committed to this training. It also demonstrates the need for governments to engage with the private sector to invest in sustainable adaptation policies and practices.

\section{Energy policy in Mauritius}

In 2007, the Mauritian government adopted an Energy Policy 2007-2025. Towards a Coherent Energy Policy for the Development of the Energy Sector in Mauritius (Republic of Mauritius 2009). The policy was developed with a consultative multi stakeholder perspective and recognises the importance of energy in the context of economic development and environmental sustainability. The key aim of the policy is to diversify the country's energy supply, improve energy efficiency, address environmental and climate changes and modernise the energy infrastructure in order to meet the challenges ahead. It recognised the issues of security of supply, affordability and the rapid shift to a low carbon, efficient and environmentally benign system of energy supply. A high barrier to effective implementation is identified as changing the habits of decision-makers who influence policy and it places great importance on the collaboration and participation of the private sector and other stakeholders.

As far as increasing renewable energy the Mauritian government is encouraging greater use of renewable and clean energy to reduce the country's dependence on fossil fuels and decrease greenhouse gas emissions. The aim is to increase the use of renewable sources of energy from the current $22 \%$ to $35 \%$ by 2025 , through wind farms, solar energy, biomass and waste-to-energy projects. Progress towards this is difficult to assess as renewable energy has a capacity that is only obtainable in ideal conditions (solar is less efficient on hazy days), hence it is better to use country comparators to assess the potential impact. Given this, forecasts (CIA 2018) suggest that Mauritius could produce $14 \%$ of total installed electricity capacity came from renewable sources. 
ISLANDS IN THE ENERGY STREAM: REGIONAL COOPERATION IN THE INDIAN ...

Table 1. Mauritius production capacities per energy source

\begin{tabular}{|l|r|r|r|r|r|}
\hline \multirow{2}{*}{$\begin{array}{l}\text { Energy } \\
\text { source }\end{array}$} & total & percentage & percentage & per capita & per capita \\
\cline { 2 - 6 } Fossil fuels & $6.19 \mathrm{bn} \mathrm{kWh}$ & $79.0 \%$ & $49.2 \%$ & $4,892.28 \mathrm{kWh}$ & $\begin{array}{r}8,120.79 \\
\mathrm{kWh}\end{array}$ \\
\hline $\begin{array}{l}\text { Nuclear } \\
\text { power }\end{array}$ & $0.00 \mathrm{kWh}$ & $0.0 \%$ & $7.0 \%$ & $0.00 \mathrm{kWh}$ & $1,155.06$ \\
\hline $\begin{array}{l}\text { Water } \\
\text { power }\end{array}$ & $\begin{array}{r}548.20 \mathrm{~m} \\
\mathrm{kWh}\end{array}$ & $7.0 \%$ & $24.1 \%$ & $433.49 \mathrm{kWh}$ & $\begin{array}{r}\mathrm{kWh} \\
\hline \begin{array}{l}\text { Renewable } \\
\text { energy }\end{array}\end{array}$ \\
\hline $\begin{array}{l}\text { Total } \\
\text { production } \\
\text { capacity }\end{array}$ & $7.10 \mathrm{bn} \mathrm{kWh}$ & $14.0 \%$ & $19.7 \%$ & $866.99 \mathrm{kWh}$ & $\mathrm{kWh}$ \\
\hline
\end{tabular}

Source: World Bank (2018a).

According to the World Bank data Mauritius can provide itself completely with self-produced energy. The total production of all electric energy producing facilities is 3 bn $\mathrm{kWh}$ per year (per capita this is an average of $\mathbf{2 , 1 5 6}$ ) which is $107 \%$ of own requirements.

\section{Energy and the tourism sector in Mauritius}

The tourism sector is identified within the Mauritius Energy Policy 2007- 2025 (Republic of Mauritius 2009). Recognition is given to the economic benefits that tourism supplies and a target of 1.5 million tourists. This, coupled with the identification of higher fuel prices and a growing awareness of the negative environmental impacts of long-distance air travel, could reduce the number of tourists travelling to Mauritius. There is awareness of the competitiveness of the tourism market and an aspirational objective to promote zero-carbon-footprint holidays. Recognition is provided that energy efficiency and renewable energy 
solutions are a necessity to host additional tourists. The key strategies identified to support the tourism sector are:

- retrofitting of existing hotels with the latest energy efficient technologies and mandatory sustainable building design for new hotels

- mandatory use of solar hot water systems in hotels as far as practicable

- introduction of low-energy lighting/appliances/air-conditioning and cooling devices throughout the hotel industry

- promotion of low-energy and eco-friendly airport transfer policies

- encouraging hotels to provide facilities on optional basis to allow tourists to offset the carbon impact of their flights by investing in sustainable energy schemes in Mauritius

- incentive schemes to promote and develop an eco-friendly tourism industry.

\section{Energy policy in Seychelles}

The Seychelles energy policy was ratified slightly later than the Mauritian one, in 2010. The policy covers an ambitious 20 years and has a sustainable focus, emphasising energy efficiency, renewable energy and reducing the dependence on oil to improve energy security. The key aim is to diversify the energy supply, a 5\% and 15\% share of renewable energy is targeted for 2020 and 2030 respectively (Republic of Seychelles 2009). The Seychellois government intend to concentrate on four renewable technologies as they are deemed more appropriate in the country: solar PV, wind, micro-hydro, and biomass/municipal solid waste (Seychelles Energy Commission 2014).

Seychelles has a higher reliance than Mauritius (91\%) compared to (79\%) on imported fuels. Various petroleum fuels are imported every year, of which gas oil, fuel Oil and Jet A1 represent $94 \%$ by mass of imports. The Seychelles can provide themselves completely with self-produced energy. The total production of all electric energy-producing facilities is $325.5 \mathrm{~m} \mathrm{kWh}$ (per capita this is an average of $3,396 \mathrm{kWh}$ ) $108 \%$ of own requirements, similar to Mauritius. There is no explicit 
link to energy within the tourism master plan. This contrasts with Mauritius that identifies tourism as a specific subsector in the energy policy document.

Table 2. Seychelles production capacities per energy source

\begin{tabular}{|l|r|r|r|r|r|}
\hline \multirow{2}{*}{$\begin{array}{l}\text { Energy } \\
\text { source }\end{array}$} & $\begin{array}{r}\text { total } \\
\text { on the }\end{array}$ & $\begin{array}{r}\text { percentage } \\
\text { on the } \\
\text { Seychelles }\end{array}$ & percentage & per capita & per capita \\
\hline Fossil fuels & $701.50 \mathrm{~m} \mathrm{kWh}$ & $91.0 \%$ & $49.2 \%$ & $7,319.27 \mathrm{kWh}$ & $\begin{array}{r}\text { on the } \\
\text { Seychelles }\end{array}$ \\
\hline Nuclear power & $0.00 \mathrm{kWh}$ & $0.0 \%$ & $7.0 \%$ & $0.00 \mathrm{kWh}$ & $1,155.06 \mathrm{kWh}$ \\
\hline Water power & $0.00 \mathrm{kWh}$ & $0.0 \%$ & $24.1 \%$ & $0.00 \mathrm{kWh}$ & $3,979.85 \mathrm{kWh}$ \\
\hline $\begin{array}{l}\text { Renewable } \\
\text { energy }\end{array}$ & $69.38 \mathrm{~m} \mathrm{kWh}$ & $9.0 \%$ & $19.7 \%$ & $723.88 \mathrm{kWh}$ & $3,276.60 \mathrm{kWh}$ \\
\hline $\begin{array}{l}\text { Total } \\
\text { production } \\
\text { capacity }\end{array}$ & $770.88 \mathrm{~m} \mathrm{kWh}$ & $100.0 \%$ & $100.0 \%$ & $8,043.15 \mathrm{kWh}$ & $16,500.88 \mathrm{kWh}$ \\
\hline
\end{tabular}

Source: World Bank (2018b).

\section{Energy and the tourism sector in Seychelles}

The Seychelles energy policy does recognise that tourism alongside rapid economic growth has resulted in increased energy demand. The Principal Secretary for Tourism stated 'being a Small Island Developing State we are vulnerable to external factors due to our size, location and exposure to global environmental challenges including the impact of climate change, hence finding the right balance for sustainable development in SIDS is imperative' (Ministry of Tourism, Seychelles 2017). The Seychelles Tourism Department operate the Seychelles Sustainable Tourism Label (SSTL) certification for hotels and many of the strategies outlined in Mauritius are encouraged within the Seychellois tourism sector. An illustration of the proactive approach that has been undertaken was a specialist 
Masters class on Sustainable tourism and energy efficiency (2017) and was attended by participants from the public and private sectors and graduate students.

\section{Sustainability education policies in Mauritius and Seychelles}

In looking at the nexus between energy, tourism and sustainable development, the role of education, both formal and informal, is crucial. To address issues of sustainability key messages need to be conveyed, understood and acted upon throughout all levels of a national community. This applies in both the public and private spheres. Valuing sustainability needs to be embedded within households, local and national government bodies and the business community. Of course, education is only as useful as the capacity allowed to make informed choices. Many people and communities who are fully aware that their actions may have short-term benefits but long-term costs, yet they may feel they have very restricted options. Environmental sensibilities and practices have often been portrayed as middle-class luxuries, which lower income households can simply not afford.

Both Mauritius and the Seychelles have well-developed education systems. Both have national universities and independent schools and colleges that focus on vocational training aimed at developing local capacity in the tourism sector. The University of Mauritius has a broad range of Faculties encompassing Agriculture, Engineering, Science, Law and Management, Social Sciences and Humanities (UoM 2019). Interestingly there is no specific Faculty or School focussing on either environmental issues or tourism. However, Mauritius does have a separate International School of Hospitality and Tourism Management (Vatel 2019), but this does not highlight adaptation to climate change or broader sustainability issues in its prospectus. In comparison the University of the Seychelles has a dedicated Department of Tourism and offers a Masters programme in Sustainable Tourism Management (UoS 2019). It is also home to the James Michel Blue Economy Research Institute (BERI 2019). BERI operates as an umbrella body for entities affiliated to the University, such as the Island Biodiversity \& Conservation Centre (IBC centre) and the University Centre for Environmental Education 
(UCEE). BERI's remit covers 'social and cultural related aspects of the Blue Economy; ocean governance; ecosystem change and modelling; ecosystem services; natural capital; renewable energy; biotechnology; sea-based products, fisheries and aquaculture; maritime transport and services; coastal and marine ecotourism; climate change; disaster risk reduction; pollution and waste management' (BERI 2019). Whist acknowledging the breadth and depth of this research it is clear that aspects of renewable energy and sustainable tourism strategies are key aspects of this institutes work.

In the Pacific region there have been innovative steps taken to integrate climate change adaptation measures into the formal education and training sector (Mcleod et al. 2019). This is something that could provide a model for similar approaches to be undertaken in Mauritius, Seychelles and the broader Indian Ocean region. The European Union-funded Pacific Technical and Vocational Education and Training in Sustainable Energy and Climate Change (PACVET 2019) project takes a regional approach with 15 SIDS governments accrediting climate change adaptation qualifications nationally and in tandem. Each of the governments involved maintain sovereign control over the accreditation process, but this is coordinated in such a way that these national qualifications are mutually recognised across the region. This facilitates the sharing of trainers and related resources and, crucially, the mobility of qualified professionals across the region. If these qualifications could be adopted in other regions, such as the Caribbean or the Indian Ocean, then this would enhance the sharing of good practice and upgrade the human capital capacity to address the challenges of climate change mitigation, resilience and adaptation.

The PACVET process began with a 'needs and gaps' analysis across the Pacific region and the creation of training materials and certification benchmarks in the fields of sustainable energy (SE), disaster risk reduction (DRR) and climate change adaptation (CAA). In line with the neo-functionalist approach of 'form follows function', as mentioned above, the 'function' required was to fill the identified gaps in SE, DRR and CAA. These extend beyond the formal education and training measures. This is a necessary platform upon which to build a comprehensive 'form' that involves all relevant stakeholders within each sovereign territory and across the region. The first intake for these new qualifications is only happening in 2018 so it 
will still be some time before the first graduates feed into the relevant fields of employment. What can be identified though is the type of skills that can be developed and the sectors where they can be most usefully deployed. For example, electrical engineers are now being trained with the specific intent of developing the solar power industry across the Pacific region. It is not the case that such electrical engineer training was not available previously, but now this is more strategically targeted with a focus on up-skilling and expanding the region's renewable energy capacity. Significantly this also ties in with the priority areas of donor countries and agencies that are now more willing to support such initiatives as they coincide with donor priority areas, in this case supporting the shift from reliance on imported fossil fuels to domestically produced and managed renewable energy sources. There is also an additional, positive impact of creating domestic employment opportunities and addressing the issue of out-migration, which is a serious issue among many SIDS, the extent of these approaches do not appear to be reflected within the Seychelles and Mauritius policies.

Seeking educational and employment opportunities outside of SIDS are among several issues impacting on the demographic composition of these island communities. Migration from these islands is often presented in the international media as escaping from low-lying territories at risk of inundation (Julca, Paddison 2010). Whilst there is some truth to this narrative it is also the case that many working-age people feel that their opportunities and life chances would be enhanced overseas, regardless of environmental degradation at home. Importantly it is the younger generation that are likely to feel this pull most strongly, as they are of an age where they are more readily accepted for training and to be offered skilled, professional employment. This is not to say that more 'traditional' skill sets, such as sustainable subsistence living in outer islands, should not be equally valued. However, a mobile workforce can be seen in both positive and negative terms. If this is a simple one-way process of 'brain drain' then this undermines the human capital capacity of societies and economies where the brightest and the best talents are siphoned off to core economies elsewhere. Alternatively, the PACVET project encourages mobility within the Pacific region but sees this as more of a circular process whereby skilled workers can move relatively freely across the region, 
facilitated by a region-wide recognition of their qualifications, and a collaborative approach to drawing on a shared pool of talent. As a model there is enormous potential for this type of formal training on a region-wide basis to be replicated in other regions of the world, notably the Indian Ocean.

For such an approach to be put in place in the Indian Ocean region several key elements need to be addressed. For PACVET the financial support of the European Union and the creation of a management structure to coordinate a region-wide framework for consultation and subsequent implantation was a key factor in the success of the project. This does not have to be an essential element for a similar project to be developed elsewhere, but there does need to be a recognition that some form of coordinating oversight has to be put in place, with at least 'start-up' funding to allow the initial 'needs and gaps' analysis to take place and to facilitate buy-in from the relevant governments and their Education Ministers. Beyond this the support of the private sector, not just the tourism industry, is important to ensure that meaningful job opportunities would be available for those qualified in SE, DDR and CCA. Although not directly part of the PACVET project there are several spin-off benefits from creating these employment opportunities. It will go some way towards tackling the issues of outmigration among SIDS' workforce (particularly within the tourism sector), it will generate additional wage income for domestic households, thereby reducing reliance of unreliable remittance payments. This increased household income also addressed many of the negative aspects of cycles of poverty, including health issues and enabling further educational opportunities. Whilst not wishing to present such projects as universal panaceas for all development needs in SIDS, the benefits of such vocational training extend far beyond the up-skilling of the individuals being trained.

\section{Regional cooperation in a global context}

As outlined above both Mauritius and Seychelles are well aware of the pressing need to move away from a damaging and unsustainable reliance on imported fossil fuels for energy security. Both governments have ambitious plans to transfer to 
greater production and consumption of renewable energy. This is to be undertaken in partnership with relevant domestic stakeholders in the private sector and civil society. The Regional Renewable Energy Forum provides an appropriate framework for the sharing of good practice across the broader Indian Ocean region. This analysis has highlighted the potential for regional cooperation among SIDS to engage with the issue of economies of scale and to undertake initiatives similar to the PACVET project. IRENA and the SIDS Lighthouses Initiative also demonstrate a willingness among these states, and related donor agencies, to promote renewable energy security policies and practices.

Despite these very positive initiatives and actions they do need to be viewed within the broader context of ongoing greenhouse gas emissions and related climate change. As mentioned earlier, the latest report from the Intergovernmental Panel on Climate Change indicates that in order to keep within the 1.5 degree target for global warming there will need to be massive investment in the renewable energy sector, in addition to carbon capture and other mitigation strategies (IPCC 2018). The IPCC Fifth Assessment Report (2014) report indicates the world's governments and industries have only twelve years to attempt to reverse current climate change trends or risk 'climate catastrophe'. Significantly such a catastrophe, should it occur, will have more profound impacts on some communities more than others. For example, although the United States has experienced an increased number of powerful hurricanes and other extreme weather events in recent years these have only devastated certain local areas and had, therefore, only a relatively minor impact on the national economy. This is not the case for SIDS, such as Mauritius and the Seychelles, where such events would have major consequences for the whole of these countries. The example of a major catastrophe devastating a whole island group would be dramatic and widely reported. However, the slow 'drip, drip, drip' of unsustainable energy policies and creeping sea-level rise making these low-lying communities increasingly insecure is no less concerning for those living on these SIDS.

The challenges of achieving sustainable development are particularly acute for low-lying SIDS. The tourism sector in these islands contributes both economically and also to greenhouse gas emissions; it is in this context that the scope of the 
industry could also be used as a vector to train the workforce about climate change. The direct educational benefits would be to upskill the tourism workforce and reduce outward migration of the population and improve the operational practises within the tourism industry to reduce GHG emissions. The indirect benefits would be the increased awareness of the local residents with the aim of transferring improved environmental behaviours into households. At a nation state level, the examples of CARICOM, Pacific Islands Forum and the over-arching AOSIS demonstrate that many SIDS recognise common causes and have become adept at sharing diplomatic resources and becoming impactful negotiators in relevant international bodies, such as the IPCC. The Indian Ocean Commission (IOC 2019) and the Indian Ocean Rim Association (IORA 2019) are appropriate bodies for the islands of the Southwest Indian Ocean to convene and collaborate to address SDG 7 (affordable and clean energy) there is also greater opportunity for collaboration within the tourism sector to overcome some of the perennial challenges of meeting the SDGs.

\section{Conclusion}

The conclusions of this study are twofold. First, within the tourism sector in Mauritius and the Seychelles, there is a recognition that reliance on fossil fuel imports is both unnecessarily costly and the resulting emissions contribute to climatic conditions that threaten the longer-term survival of these territories. As noted above, this awareness extends well beyond the tourism sector and informs both governments' priorities and sustainability education policies. Second, while the case study approach undertaken here has provided relevant data for these island states there are important lessons for other states. Island states, especially the lowerlying ones, are acutely aware of the threats posed by climate change and related extreme weather events. The fact that many such states are also significantly reliant on income generated by the tourism sector highlights the need to operate and promote this sector in a sustainable manner. Notwithstanding the specificities of 
these case studies, the issue of moving away from fossil fuel reliance to more sustainable, renewable sources of energy has much broader applicability.

Recent IPCC meetings have highlighted the vulnerability of small island states being on the 'front line' of climate change (IPCC 2020). They have been used as metaphors for much larger global patterns and processes to stimulate decarbonisation among industrialised economies. Whilst focusing on the tourism sector this study has also demonstrated the need for coordinated action between numerous public and private stakeholders and the importance of community engagement to implement sustainable practices. Some progress has been made with a growing awareness of the pressing need to decarbonise the global economy. A number of energy companies have taken on this challenge, albeit with a relatively small percentage of their overall businesses investing in the required research and development of renewables. There remain huge challenges to move away from fossil fuels to renewable forms of energy at the global level. However, this study demonstrates that with enough incentives, and political will, such transformations are both possible and practical.

\section{References}

Asif M., Muneer T. (2007), Energy supply, its demand and security issues for developed and emerging economies, "Renewable and Sustainable Energy Reviews", vol. 11 no. 7, pp. 1388-1413.

BERI (2019), Blue Economy Research Institute, https://beri.unisey.ac.sc/ [24.03.2019].

CARICOM (2019a), CARICOM Community for All, https://caricom.org/ [24.03.2019].

CARICOM (2019b), CARICOM Community for All, https://energy.caricom.org/about/ [24.03.2019].

CIA (2018), Central Intelligence Agency CIA World Factbook 2018-2019, Skyhorse Publishing, Washington D.C.

Climate Analytics (2018), $1.5^{\circ} \mathrm{C}$ temperature limit - key facts, https://climateanalytics.org/briefings/15c-key-facts/ [08.10.2018].

Gnana J. (2018), Abu Dhabi fund allocates \$17 million to Seychelles renewable projects, https://www.thenational.ae/business/energy/abu-dhabi-fund-allocates-17m-to-seychelles-renewableprojects-1.712474 [12.03.2020].

Haas E.B. (1968), The uniting of Europe. Political, social and economic forces 1950-1957, Stanford University Press, Stanford. 
Hadush S.Y., Ravi Kumar Bhagwat S. (2019), A comparative study of renewable energy and electricity access policies and regulatory frameworks in the Indian Ocean islands. The case of Mauritius, Seychelles, Madagascar and Comoros, https://www.irena.org/events/2019/Apr/Regional-Forum-onSustainable-Energy-in-the-Indian-Ocean-islands [05.03.2019].

Hughes T.P., Barnes M.L., Bellwood D.R., Cinner J.E., Cumming G.S., Jackson J.B., Kleypas J., Van De Leemput I.A., Lough J.M., Morrison T.H., Palumbi S.R. (2017), Coral reefs in the Anthropocene, "Nature", vol. 546 no. 7656, pp. 82-90.

International Energy Agency (IEA) (2018), Tracking SDG7. The Energy Progress Report 2018, World Bank, Washington D.C., https://www.irena.org/-

/media/Files/IRENA/Agency/Publication/2018/May/SDG7_Tracking_report_executive_summary_201 8.pdf [12.04.2019].

IOC (2019), Indian Ocean Commission, https://sustainabledevelopment.un.org/partnership/partners/?id=1832 [19.11.2019].

IORA (2019), Indian Ocean Rim Association, https://www.iora.int/en/events-medianews/events/priorities-focus-areas/blue-economy/2018/iora-and-fao-2018 [19.11.2019].

Intergovernmental Panel on Climate Change (IPCC) (2007), Climate change 2007. Synthesis report. Contribution of Working Groups I, II and III to the Fourth Assessment Report of the Intergovernmental Panel on Climate Change, core writing team: Pachauri R.K, Reisinger A. (eds.), IPCC, Geneva.

IPCC (2011), Summary for policymakers, in: IPCC Special Report on renewable energy sources and climate change mitigation, Edenhofer O. et al. (eds.), Cambridge University Press, Cambridge - New York.

IPCC (2018), Global warming of $1.5^{\circ} \mathrm{C}$, an IPCC Special Report on the impacts of global warming of $1.5^{\circ} \mathrm{C}$ above pre-industrial levels and related global greenhouse gas emission pathways, in the context of strengthening the global response to the threat of climate change, sustainable development, and efforts to eradicate poverty, http://www.ipcc.ch/report/sr15/ [05.03.2019].

IPCC (2020), IPCC-52, Paris, https://www.ipcc.ch/meeting-doc/ipcc-52/ [05.03.2020].

International Renewable Energy Agency (IRENA) (2019), Regional Forum on Sustainable Energy in the Indian Ocean islands, https://www.irena.org/events/2019/Apr/Regional-Forum-on-SustainableEnergy-in-the-Indian-Ocean-islands [05.03.2019].

Julca A., Paddison O. (2010), Vulnerabilities and migration in small island developing states in the context of climate change, "Natural Hazards", vol. 55 no. 3, pp. 717-728.

Lenzen M., Sun Y.Y., Faturay F., Ting Y.P., Geschke A., Malik A. (2018), The carbon footprint of global tourism, "Nature Climate Change", vol. 8 no. 6, pp. 522-528.

Mcleod E., Bruton-Adams M., Förster J., Franco C., Gaines G., Gorong B., James R., Posing-Kulwaum G., Tara M., Terk E. (2019), Lessons from the Pacific Islands. Adapting to climate change by supporting social and ecological resilience, "Frontiers in Marine Science", https://www.frontiersin.org/articles/10.3389/fmars.2019.00289/full [17.03.2020]. 


\section{Roy SMITH, Rachel WELTON}

McKendry P. (2002), Energy production from biomass. Part 1: Overview of biomass, "Bioresource Technology", vol. 83 no. 1, pp. 37-46.

Ministry of Tourism, Maldives (2014), Tourism Yearbook 2014, https://www.tourism.gov.mv/pubs/tourism_yearbook/tourism_year_book_2014.pdf [24.03.2019].

Ministry of Tourism, Seychelles (2017), Seychelles explores energy efficiency in the tourism sector with the help of experts from the Dutch Caribbean island of Aruba, https://www.seychellestourismboard.travel/news-media/press-releases/250-seychelles-explores-energyefficiency-in-the-tourism-sector-with-the-help-of-experts-from-the-dutch-caribbean-island-of-aruba [23.09.2018].

Mundi Index (2018), Mauritius - International tourism, number of arrivals https://www.indexmundi.com/facts/mauritius/international-tourism [15.04.2019].

National Bureau of Statistics (NBS) (2018), Seychelles visitor arrivals, 2017, https://www.nbs.gov.sc/statistics/tourism [12.08.2019].

Oreskes N. (2004), The scientific consensus on climate change, "Science", vol. 306 no. 5702, p. 1686.

PACVET (2019), Pacific Community. The European Union Pacific Technical and Vocational Education and Training on Sustainable Energy and Climate Change Adaptation (PACTVET), https://gem.spc.int/projects/pactvet [08.10.2019].

PCREEE (2019), Pacific Centre for Renewable Energy and Energy Efficiency, https://www.pcreee.org/ [21.03.2019].

Pinkse J., Kolk A. (2012), Addressing the climate change - sustainable development nexus. The role of multistakeholder partnerships, "Business \& Society", vol. 51 no. 1, pp. 176-210.

Republic of Mauritius (2009), Ministry of Renewable Energy \& Public Utilities, Long-term energy strategy,

https://sustainabledevelopment.un.org/content/documents/1245mauritiusEnergy\%20Strategy.pdf [12.08.2019].

Republic of Seychelles (2009), Energy policy for the Republic of Seychelles 2010-2030, http://www.iea.org/policiesandmeasures/pams/seychelles/name-37155-en.php [12.08.2019].

Republic of Seychelles (2015), Intended Nationally Determined Contribution (INDC) under the United Nations Framework Convention on Climate Change, Government of Seychelles, https://www4.unfccc.int/sites/ndcstaging/PublishedDocuments/Seychelles\%20First/INDC\%20of\%20S eychelles.pdf [09.08.2019].

Republic of Seychelles, Seychelles Energy Commission (2011), Seychelles Energy Report for 2010, http://www.sec.sc/images/archives/energy-report/Seychelles-Energy-Report-for-2010-28A.pdf [20.09.2018].

Robbins A. (2016), How to understand the results of the climate change summit: Conference of Parties21 (COP21) Paris 2015, "Journal of Public Health Policy", vol. 37, pp. 129-132. 


\section{ISLANDS IN THE ENERGY STREAM: REGIONAL COOPERATION IN THE INDIAN ...}

Seychelles Energy Commission (2014), Technical specifications for grid-connected photovoltaic power systems, http://www.caymaninstitute.org.ky/pdf/Sey chelles_Grid-Connected_PV_Power_Systems.pdf [26.11.2019],

Seychelles News Agency (2016), Seychelles see signing of Paris Agreement as environmental turning point,

$\mathrm{http} / / / \mathrm{www} \cdot$ seychellesnewsagency.com/articles/5056/Seychelles+sees+signing+of+Paris+Agreement+a s+environmental+turning+point [14.10.2018].

Shah D. (2019), Extinction Rebellion: radical or rational?, "British Journal of General Practice", vol. 69 no. 684 , pp. 345-345.

United Nations Development Programme (UNDP) (2019), Goal 7: Affordable and clean energy, https://www.undp.org/content/undp/en/home/sustainable-development-goals/goal-7-affordable-andclean-energy.html [23.04.2019].

UNEP, WTO (2012), United Nations Environment Programme and World Tourism Organization Tourism in the Green Economy - Background Report, UNWTO, Madrid.

United Nations (2008), UN Department of Economic and Social Affairs: Division for Sustainable Development, https://www.un.org/esa/sustdev/sids/sids.htm [28.03.2019]

United Nations World Tourism Organization (UNWTO) (2008), Climate change and tourism responding to global challenges, https://www.e-unwto.org/doi/book/10.18111/9789284412341 [18.09.2019].

UNWTO (2012), Challenges and opportunities for tourism development in small island developing state, UNWTO, Madrid, https://www.nbs.gov.sc/statistics/tourism [15.04.2019].

UNWTO (2017), Tourism highlights 2017, UNWTO, Madrid, https://people.unica.it/carlamassidda/files/2017/06/UNWTO_Tourism-Highlights_2017.pdf [18.09.2019].

UNWTO (2018), World Tourism Organization Tourism for Development - Volume I: Key Areas for Action, UNWTO, Madrid, Available at: https://www.e-unwto.org/doi/pdf/10.18111/9789284419722 [25.4.19]

UoM (2019), University of Mauritius, https://www.uom.ac.mu/fssh/index.php/90-foa/social-studies [28.03.2019].

UoS (2019), University of Seychelles, https://unisey.ac.sc/ [28.03.2019].

Vatel (2019), Hotel \& Tourism Business School, Mauritius, https://www.vatel.mu/en/infos/search [28.03.2019].

World Bank (2018a), Progress on world energy goals slow, but strong gains in countries show promise, World Bank, Washington DC, https://www.worlddata.info/africa/mauritius/energy-consumption.php [23.04.2019]. 
World Bank (2018b), Progress on world energy goals slow, but strong gains in countries show promise, World Bank, Washington DC, https://www.worlddata.info/africa/seychelles/energy-consumption.php [23.04.2019].

World Bank SDG (2018), https://www.worldbank.org/en/news/press-release/2018/05/02/sustainabledevelopment-goal-sdg-7-global-progress-report [17.03.2020].

World Meteorological Organisation (2018), State of the climate in 2018, https://public.wmo.int/en/media/press-release/state-of-climate-2018-shows-accelerating-climatechange-impacts [05.03.2020].

World Tourism Organization (2018), Tourism for development. Vol. I: Key areas for action, UNWTO, Madrid, https://doi.org/10.18111/9789284419722 [25.04.2019].

Zeebe R.E. (2013), Time-dependent climate sensitivity and the legacy of anthropogenic greenhouse gas emissions, "Proceedings of the National Academy of Sciences", vol. 110 no. 34, pp. 13739-13744. 